\title{
"As vitrines" de Chico Buarque: exercício de análise
}

$\frac{\text { LUIz Tatit e IVÃ Carlos LOPES }}{\text { Universidade de São Paulo - USP }}$ 


\section{Resumo}

Na canção "As Vitrines", Chico Buarque relata a trajetória de um sujeito apaixonado a perseguir a amada pelas ruas da cidade, sem nunca obter dela qualquer resposta efetiva, nem mesmo qualquer sinal de que ela nota sua existência. Letra e melodia contribuem, cada qual a seu modo, para retratar a ambigüidade da situação desse sujeito que pode ver, sem poder tocar.

\section{Palavras-chave}

canção; enunciação; percepção

\section{Abstract}

In his song "As Vitrines", Brazilian composer Chico Buarque tells the story of a man deeply in love who follows his beloved as she walks through the streets of a big city. He gets absolutely no response from her, not even a single clue that she's aware of his existence. Music and lyrics support each other in painting the highly ambiguous situation of such a hero who is able to see, even though he's not allowed to touch what he sees.

\section{Keywords}

song; enunciation; perception 


\section{Introdução}

$\mathbb{E}$

scolhida como trilha sonora de abertura da novela Sétimo Selo, levada ao ar pela Rede Globo no início da década de 1980, a composição "As Vitrines", de Chico Buarque, conheceu uma difusão popular extraordinária, muito além do que se espera no universo das criações de alta elaboração estética. Seus contornos melódicos e sua letra carregada de reverberações imagéticas integravam-se de tal forma às figuras visuais programadas para introduzir os capítulos diários da trama que os telespectadores sentiam-se verdadeiramente hipnotizados diante da combinação de todos aqueles efeitos sensoriais.

No próprio encarte do álbum, ainda no formato de LP, em vez da simples apresentação da letra de "As Vitrines", encontravase um trabalho gráfico de espelhamento das estrofes, contendo até mesmo uma outra versão de seus segmentos lingüísticos formada a partir de anagramas dos versos principais. Todos esses sinais indicam que a composição já nasceu impregnada de múltiplos sentidos e dimensões e que isso aos poucos a transformou, pelo menos no âmbito de seus ouvintes mais atentos, num convite irresistivel à análise e interpretação de seus conteúdos.

Motivados pelos aspectos mencionados, mas ao mesmo tempo restringindo-nos às significações veiculadas pelo canto do compositor, examinaremos neste ensaio os recursos de ajuste entre melodia e letra que asseguram em boa medida o impacto desta canção. 


\section{Domínio da melodia}

No que se refere ao aspecto musical, toda canção de consumo apresenta um campo de direções melódicas, regulado por uma tonalidade básica que pouco se altera durante a breve duração da obra. A atividade modulatória reduz-se em geral a passagens de escala maior para menor e vice-versa, muitas vezes lançando mão de tonalidades relativas, como ocorre em nosso exemplo (primeira parte em Gm, segunda, em EbM). Mas no interior desse campo, predefinido em extensão, o compositor pode proceder a incontáveis manobras entoativas, que vão desde a exploração minuciosa dos intervalos sugeridos pela própria gama diatônica até a inserção de alturas estranhas a ela, sustentadas pelos chamados acordes dissonantes de transição. "As Vitrines" exibe uma variação considerável de inflexões melódicas que, numa avaliação apressada, poderia nos conduzir à constatação pura e simples de um recurso de mimetização das flutuações inconstantes da personagem feminina descrita na letra. Estaríamos, assim, desobrigados de identificar parâmetros de ordenação numa seqüência de contornos que parece desprezar qualquer regra de evolução. Um exame criterioso do componente melódico da canção não pode, entretanto, se contentar com abordagens desse gênero. Os termos de compatibilidade entre melodia e letra são configurados em níveis mais abstratos que exigem maior acuidade dos procedimentos descritivos.

Assim como há debreagens no plano lingüístico, convertendo enunciações em enunciados por meio de dispositivos actancial, espacial e temporal, existem maneiras de caracterizar o enunciado melódico a partir do grau de autonomia que este adquire em relação à "voz" do enunciador. Ou seja, embora tenhamos em toda canção um enunciador onipresente, responsável pelo modo de dizer - pelas entoações - que se expressa ao longo da composição, o tratamento dispensado pelo autor à linha melódica pode regular de tal modo o encadeamento de seus motivos que os aspectos instáveis dessa linha, as marcas da modulação da fala, pouco se manifestam na superfície da obra. Nesse caso, o enunciado melódico se sobrepõe à enunciação, organizando suas unidades sob um regime de concentração ou de 
expansão. O primeiro dá conta da distribuição "horizontal" dos elementos melódicos, ao enfocar suas leis de reiteração (tematização e refrão) e desdobramento, presentes sobretudo nas canções aceleradas. O segundo se encarrega das oscilações "verticais" desses elementos, ao enfocar a atuação dos saltos intervalares e das transposições de tessitura, bem como as regras de gradação que ordenam principalmente as canções desaceleradas.

\subsection{Figuras enunciativas melódicas}

Mas há canções em que os citados regimes não dispensam a "voz" do enunciador, como se praticassem uma debreagem enunciativa específica do plano melódico. Quando isso ocorre, dizemos que há figuras enunciativas convivendo com os processos enuncivos da concentração e expansão. A melodia em exame retrata bem esse fenômeno' (Fig. 1):

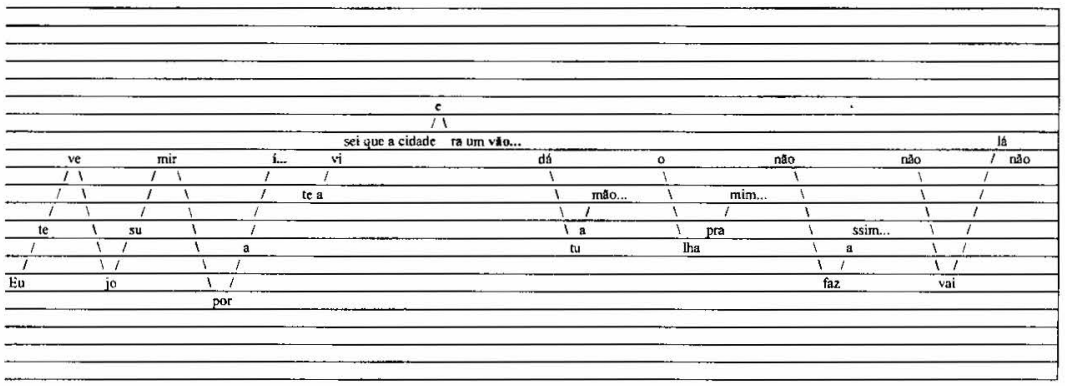

Figura 1

Observamos, desde a primeira seqüência, uma evolução pouco regular das unidades melódicas, ao longo da qual os motivos nem bem se formam já se desfazem. A canção inicia-se com um esboço de tematização sobre o verso "Eu te vejo sumir por aí" que não se confirma no fragmento subseqüente ("Te avisei que a cidade

1. Traduzimos, com tais diagramas, o complexo formado pela união da letra e da melodia da canção, destacando apenas os aspectos relevantes para a presente análise. Cada espaço entre linhas representa um semitom, e o conjunto vertical exibe a extensão da tessitura percorrida pela composição. 
era um vão"). Por outro lado, as sílabas finais mais alongadas (cf. destaques em negrito) - e ainda seguidas de pausas -dessas mesmas unidades, reforçadas pelo andamento desacelerado, poderiam indicar uma direção ascendente e, portanto, uma trajetória melódica típica do regime de expansão adotado pelas composições passionais que se definem pela reconstrução dos elos perdidos. Mas isso também não se verifica nesta fase, já que os trechos seguintes desmantelam essa orientação com seus modos entoativos de dizer a letra: "dá tua mão", "olha pra mim" etc. Na verdade, essas figuras enunciativas mantêm entre si relações de vizinhança que não se transformam em parâmetros extensos de ordenação do componente melódico. Comportam-se como entoações avulsas sem função estrutural na canção.

$2^{\mathrm{a}}$ seqüência

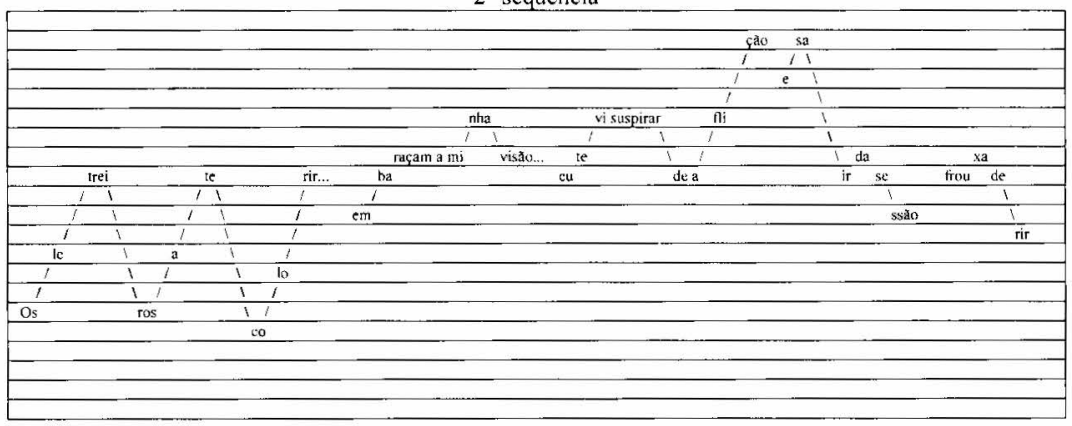

Figura 2

Nesta segunda seqüência (Fig. 2), algumas diretrizes começam a ser traçadas em meio a uma conduta geral semelhante à da primeira. A composição idêntica dos dois fragmentos melódicos iniciais - que conduzem os trechos "Os letreiros a te colorir" e "embaraçam a minha visão" - serve para caracterizar uma locução repetitiva que, neste contexto, revela um enunciador convivendo com cenas recorrentes, ao mesmo tempo previsíveis e excitantes, diante das quais se vê impelido a dar respostas a princípio desaprovadoras, mas, no decorrer do progresso melódico, cada vez mais tolerantes e envolvidas. As desaprovações tiveram como suporte entoativo os motivos desarticulados que, ao final da primeira seqüência, parecem 
vir diretamente dos desejos monopolizadores do enunciador; as respostas que demonstram envolvimento são aquelas que, a partir dessa segunda seqüência, começam a definir uma orientação melódica condizente com o "eu" narrativo que adere ao giro embriagado da personagem feminina no mundo das vitrines.

Realmente, o fragmento melódico que se eleva conduzindo o verso "Eu te vi suspirar de aflição" apresenta três funções concomitantes:

\subsection{Função local e função à distância}

(1) Perfaz, no âmbito da segunda seqüência, uma gradação ascendente, responsável por um efeito de regularidade até então inexistente nessa primeira parte (Fig. 3):

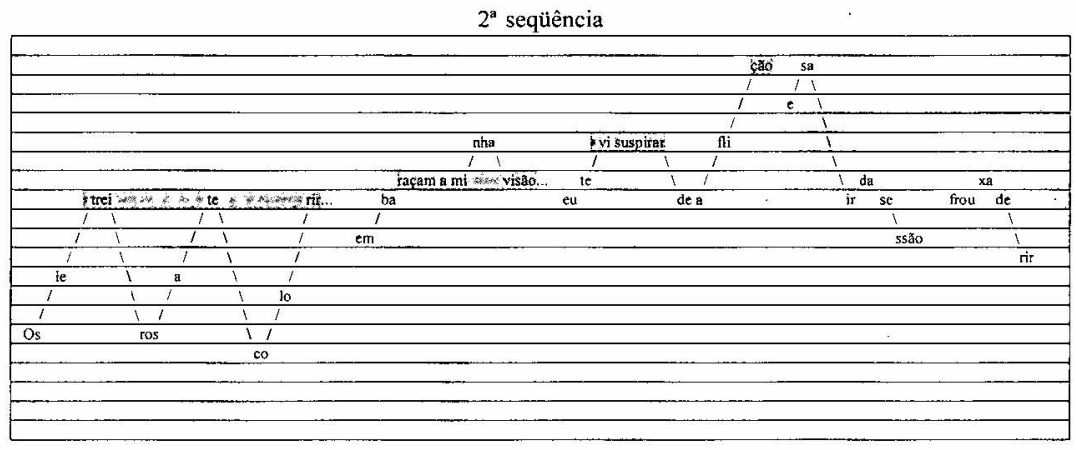

Figura 3

(2) Introduz, no âmbito global da canção, a primeira amostra da elevação ascendente que será decisiva na segunda parte da música (a partir da $3^{\text {a }}$ seqüência). Embora aparente ser um simples ressalto em seu contexto melódico imediato, esse fragmento antevê, como um lampejo, o ápice da tensão melódica que, na seqüência seguinte, será paulatinamente construída. Por isso, dizemos que o fragmento em exame possui valor à distância ou, em outros termos, função extensa no corpo da obra. A aproximação visual dos dois trechos pode esclarecer esse tipo de identidade de altura (Fig. 4): 


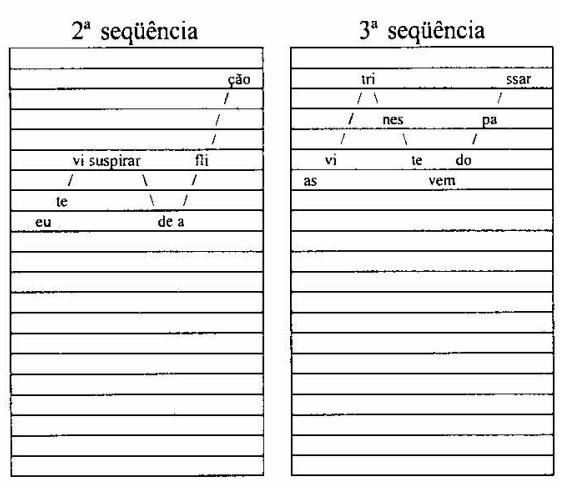

Figura 4

(3) Desempenha, enfim, uma função entoativa complementar com relação ao motivo subseqüente: eleva-se para valorizar o descenso asseverativo da frase posterior ("E sair da sessão"). Esse recurso mantém o valor local, intenso, do contorno. Se as duas funções anteriores contribuem para sustentar musicalmente as atuações do eu-narrativo, debreado no enunciado cancional como aquele que persegue os gestos da personagem feminina, a presente função figurativiza, mais uma vez, a voz do enunciador geral que observa, a boa distância, a cena da moça e seu "vigia" e manifesta, vez por outra, entoações com valor local nem sempre integradas no nível do enunciado melódico (Fig. 5):

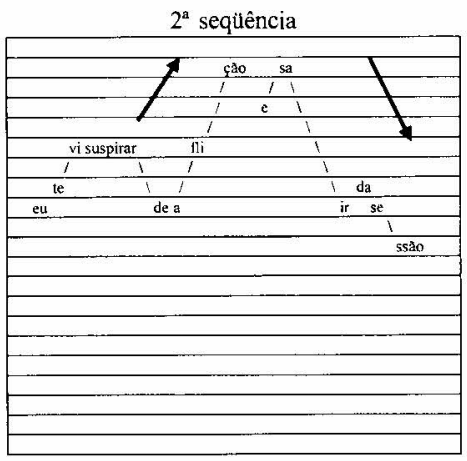

Figura 5

Esse modelo típico (elevação/descenso) de nossas inflexões cotidianas ainda recebe o reforço de uma espécie de apêndice melódico 
que acentua o tom da afirmação sobre o verso "frouxa de rir". Aparentemente desnecessário, esse fragmento entoativo cumpre sua função local de rebaixar um mínimo (um semitom) a asserção anterior, mas, além disso, registra um desenho asseverativo que, por seu caráter avulso, se alinha às modulações atribuídas ao enunciador "distante". Mal começa a segunda parte ( $3^{\mathrm{a}}$ seqüência), já temos oportunidade de reouvi-lo desempenhando o mesmo papel de asseveração individual em meio a um projeto melódico que começa a se definir como ascendente (Fig. 6):

$3^{\text {a }}$ seqüência

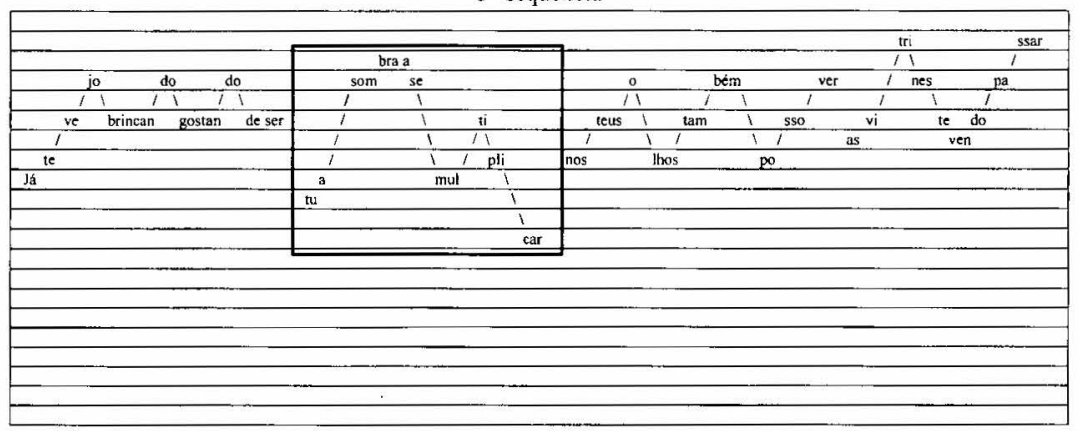

Figura 6

O perfil do trecho em destaque, alheio à tendência geral de evolução da seqüência, ainda guarda em sua terminação a memória do pequeno suplemento melódico que concluiu a primeira parte, como se fizesse ecoar a voz do enunciador mesmo já no interior do período de estruturação do enunciado. Podemos aproximar esses dois fragmentos e observar suas similaridades na Figura 7:

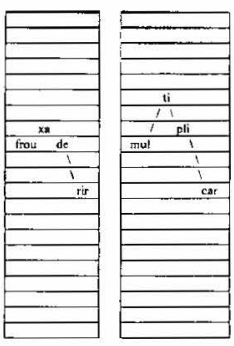

Figura 7 


\subsection{A direção melódica}

temos na terceira seqüência é uma transposição da melodia para o registro agudo do campo de tessitura e uma programação também ascendente dos motivos musicais, que estabelecem, finalmente, a orientação do canto, a mesma que, na letra, conduz o olhar do eunarrativo em direção à personagem-vitrine. Se omitirmos a intervenção do fragmento asseverativo já comentado e destacarmos as sílabas acentuadas que definem as faixas de altura, teremos (Fig. 8):

$3^{\mathrm{a}}$ seqüência

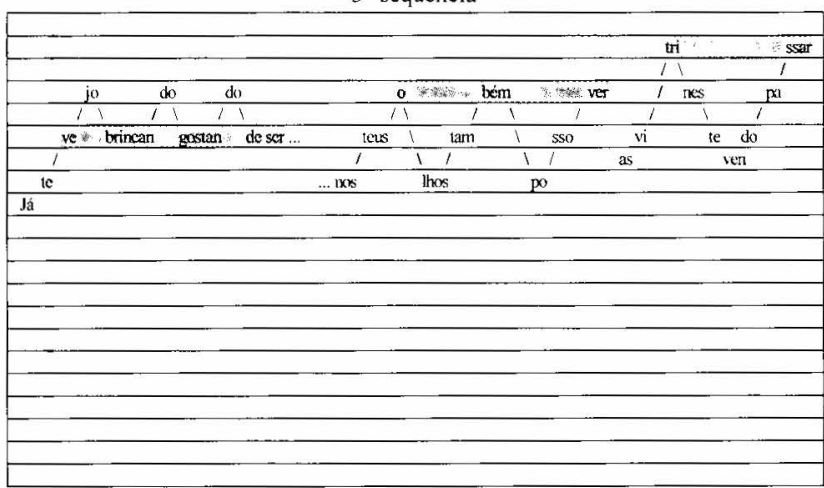

Figura 8

Essa elevação gradativa tem um destino bem definido: chegar ao fragmento melódico que conduz a locução "Na galeria" (Fig. 9). Com ele, completa-se o itinerário ascendente no topo da tessitura (cf. sílaba "ga...") e, sobretudo, atinge-se a tonalidade $(\mathrm{Gm})$ e o comportamento harmônico iniciais com uma solução melódica ainda inusitada no âmbito desta canção. Podemos dizer, assim, que a terceira seqüência tinha como projeto desembocar no motivo: 


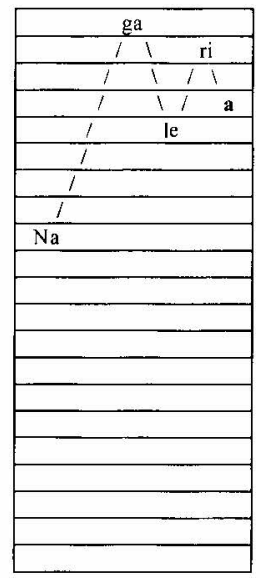

Figura 9

Importante frisar que, embora a nota mais aguda sobre a sílaba "ga..." arremate a elevação da seqüência anterior, sua função no interior do motivo é menos relevante que a da sílaba "...a", destacada em negrito. $\mathrm{O}$ mesmo se pode dizer do amplo intervalo melódico (de 8 semitons) praticado entre "Na" e "ga". Não chega a constituir um salto tensivo que mereça tratamento especial. A duração uniforme e pouco expandida de todas as alturas que antecedem a sílaba "...a", em contraste com o significativo estágio do canto sobre ela, faz com que o ponto terminativo da direção melódica se concentre de fato na sílaba vocálica.

Na verdade, esse motivo e o fragmento melódico subseqüente compõem um só pivô de passagem (Fig. 10) que tem valor central no desenvolvimento da segunda parte desta canção:

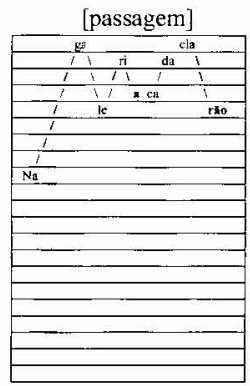

Figura 10 


\subsection{Evolução contínua e dissonâncias}

Ao reiterar o desenho que toca o ápice da tessitura e faz estágio alongado na última sílaba, a curva melódica sobre "cada clarão" sublinha a outra função, igualmente relevante, da inflexão anterior: a função incoativa. Ou seja, ao refazer em essência o contorno entoativo de "Na galeria", o segundo motivo confere ao precedente uma afirmação de conduta que servirá de abertura ao longo enunciado melódico desenvolvido em seguida. Todos os fragmentos desse enunciado terão suas durações finais fixadas em "...a" (sempre oriundo de “...ia") ou em "...ão", como se desdobrassem a fórmula desse pivô de passagem (cf., na Fig. 11, os negritos na transcrição da quarta seqüência). Portanto, além do valor terminativo já destacado anteriormente, a melodia de "Na galeria" acumula o valor incoativo, e ambos se vêem reforçados pelo encontro com a tonalidade, dispositivo harmônico que rege tanto os desfechos como os inícios melódicos.

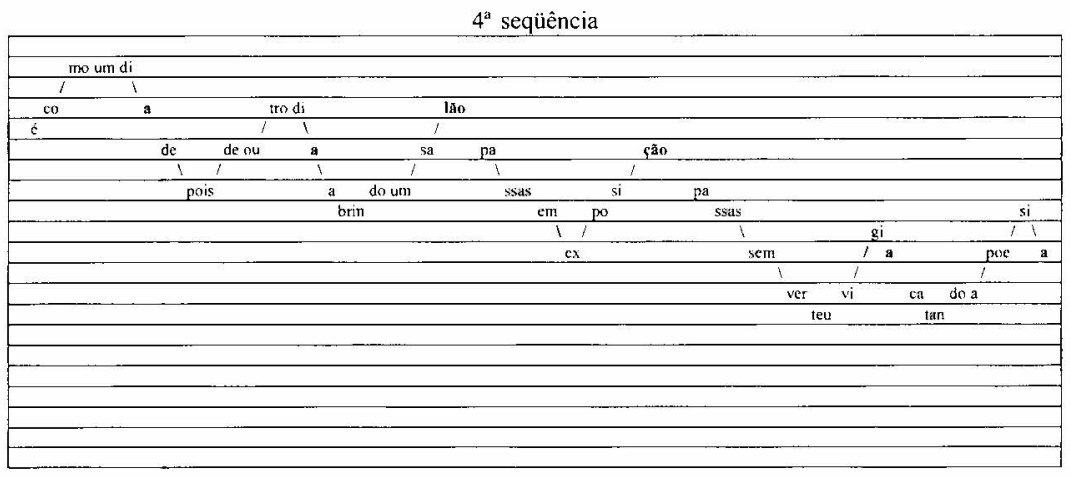

Figura 11

A exploração de tessitura desta quarta sequiência se dá por graus imediatos, procedimento que elimina da evolução melódica os saltos e as transposições de registro. As ondulações do perfil obedecem a uma disposição escalar, com intervalos de tons e semitons, que assegura a forma contínua de progresso sonoro: cada nota, apoiando-se no padrão da escala, seleciona a altura imediatamente superior ou inferior para construir a trajetória melódica. Livre do 
fenômeno de ruptura, essa conduta instaura um processo de previsibilidade semelhante ao da espera narrativa, sobretudo quando esta pressupõe uma programação gradual das etapas que devem ser cumpridas. E é esse aspecto de antevisão do percurso, tanto melódico quanto narrativo, que garante à canção um encaminhamento distensivo. Melodia e letra contribuem, assim, para a caracterização de um sujeito que se mantém a uma distância ideal de seu objeto de observação, com pleno controle do tempo-espaço que os separa.

A evolução altamente contínua desse perfil melódico não mascara outros níveis de tensividade musical que, de certo modo, contradizem o comportamento distensivo das inflexões: o emprego ininterrupto de acordes alterados e a intervenção regular dos tonemas (terminações de frases entoativas) ascendentes indicando prosseguimento melódico.

Embora a sucessão das notas respeite sempre a ordem escalar, a correlação "vertical" dessas alturas com a base harmônica, fundada em acordes dissonantes, gera efeitos de afastamento do centro tonal e de adiamento constante da conclusão melódica. É esse procedimento musical que sustenta o "passeio" da personagem feminina em meio aos clarões transparentes das vitrines e, ao mesmo tempo, assegura a idéia de que, apesar de manter um controle visual sobre a cena, o sujeito não se permite um contato físico com o objeto. Os graus imediatos descrevem um perfeito domínio da trajetória que leva a este actante, enquanto os acordes sugerem protelação indefinida do encontro.

Os tonemas ascendentes, por sua vez, revestem-se de valores passionais e figurativos que reforçam a atuação harmônica. Os estágios do canto nas sílabas em negrito atribuem a cada fragmento melódico uma direção ascendente local que soa como resistência ao encaminhamento global da seqüência, nitidamente em queda (se seguirmos essas sílabas em negrito em toda a extensão do trecho verificaremos a tendência de descenso, cf. Fig. 12). 
final da $4^{\mathrm{a}}$ seqüência

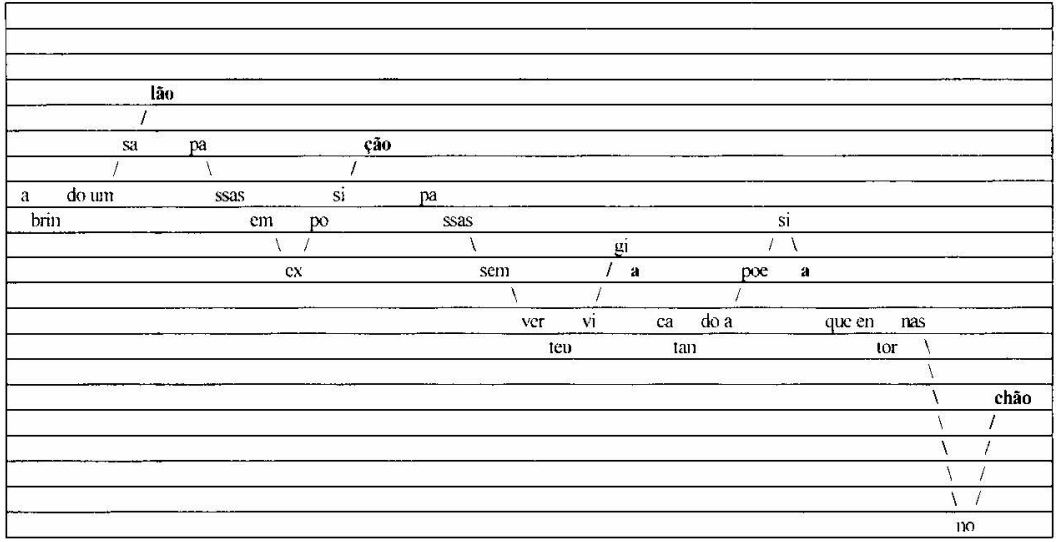

Figura 12

Acontece que a voz do enunciador geral ainda se faz ouvir nessas elevações individuais, como representante da instância que "sente falta" de um contato mais próximo ("Dá tua mão") com a personagem esquiva. A demora nos tons em terminações ascendentes quase sempre é sinal de lamento passional (passivo) e, portanto, de restrição à plena continuidade. Mas constitui também fator de ênfase do segmento ascendente próprio de toda asseveração entoativa, justamente aquele que indica continuidade do discurso e que pede a resolução do descenso. Como temos aqui uma sucessão de segmentos individuais ascendentes, podemos dizer que, também por esse enfoque, é adiado o desenlace melódico (o que faz coro com a base harmônica e com o relativo desencontro narrativo descrito na letra). Em resumo, essa resistência passional e figurativa (por se remeter às inflexões da fala cotidiana) a um descenso que, de outro modo, poderia seguir uma trilha totalmente desobstruída, garante a sobrevivência dos conteúdos de privação em meio a um contexto melódico que favorece a evolução contínua de seus elementos.

Mas é indisfarçável o arranjo enuncivo que se expressa neste final da quarta seqüência pelo movimento descendente das durações em negrito e pela sucessão rigorosa dos graus imediatos. Tem-se, então, a predominância da atuação decidida do eu-narrativo que não perde o vínculo com o objeto (daí a previsibilidade do percurso 
melódico), embora dele se distancie o suficiente para desempenhar o seu papel de observador. Deste ponto de vista, o que temos é um projeto bem definido de descendência melódica, que contracena com a elevação promovida na terceira seqüência e manifesta a aliança definitiva desse actante com o comportamento volúvel da amada, do qual, aliás, já extrai significativo proveito poético. O intervalo de quarta ascendente (5 semitons) que se dá entre as sílabas finais "no" e "chão" constitui uma forma convencional de resolução harmônica na tonalidade da música que em nada altera a progressão descendente do segmento. A explicação é simples: enquanto a nota sobre "chão" ressoa o alongamento das alturas precedentes em negrito e, portanto, confirma a tendência de descenso, o tempo sobre a sílaba "no" é irrisório.

O que torna a melodia de "As Vitrines" intrigante quando em comunhão com a letra é justamente essa convivência, ao longo do mesmo corpus sonoro, de elementos associados a uma regularidade extensa, e que refletem a adesão do eu-narrativo à dispersão da personagem feminina, e elementos de influência apenas local que intervêm como sintomas da resistência do enunciador geral às atitudes da mesma personagem.

\section{Domínio da letra}

$1 \quad$ Eu te vejo sumir por aí

2 Te avisei que a cidade era um vão

3 - Dá tua mão

4 - Olha pra mim

5 - Não faz assim

6 - Não vai lá, não

7 Os letreiros a te colorir

8 Embaraçam a minha visão

9 Eu te vi suspirar de aflição

10 E sair da sessão, frouxa de rir 
11 Já te vejo brincando, gostando de ser

12 Tua sombra a se multiplicar

13 Nos teus olhos também posso ver

14 As vitrines te vendo passar

15 Na galeria

16 Cada clarão

17 É como um dia depois de outro dia

18 Abrindo um salão

19 Passas em exposição

20 Passas sem ver teu vigia

21 Catando a poesia

22 Que entornas no chão

Desde o primeiro relance de olhos se revela uma simetria imperfeita na estruturação da letra de "As Vitrines": vemos quatro estrofes organizadas de forma tal que os segmentos intermediários, o segundo e o terceiro, apresentam o mesmo número de versos, ao passo que as estrofes englobantes, a primeira e a última, têm uma equivalência apenas aproximativa em termos de extensão. Quantitativamente falando, a última estrofe é a mais longa do conjunto. Já no que se refere à métrica, o que se nota é uma regularidade também parcial em todas as estrofes, mas em todo caso mais exata nas estrofes medianas do que nas extremas.

A história contada corresponde à "perseguição" de uma mulher observada por aquele que a deseja e que, movido por esse desejo, aparentemente não consegue deixar de acompanhar, mais ou menos na penumbra, seu deslocamento por diferentes pontos de uma cidade. O ponto de vista é globalmente o desse sujeito que mira a mulher e por cujo olhar é filtrado, ao longo do texto, tudo quanto nos é dado observar a nós, espectadores indiretos que só conseguimos saber, das cenas retratadas, aquilo que esse observador nos revela. Um sujeito apaixonado persegue, atento, a trajetória da amada pelo espaço.

Vamos operar uma distinção, desde logo, entre dois tipos de sujeitos que cada uma das personagens em cena comporta como 
funções, num determinado plano analítico. Adotaremos uma sugestão de Jacques Fontanille (Fontanille, 2003, p. 150-170), segundo a qual há interesse em diferenciar numa narrativa, por um lado, os actantes "transformacionais", tais como o Sujeito, o Objeto, o Destinador, envolvidos na trama das mudanças de estado que observamos no relato enquanto transformação de conteúdos associados ao fazer das personagens, e, por outro lado, os chamados actantes "posicionais", pressupostos pelos primeiros, e que dizem respeito às formas de apreensão de um entorno perceptível por um sujeito ali instalado como centro de observação. A idéia, nesse segundo caso, é a de um "campo posicional" dotado de um centro e de bordas (seus horizontes), e que se mede pela profundidade que os separa. O centro é ocupado pelo sujeito observador, que se concebe desde o princípio como sujeito sensível, isto é, como um sujeito simultaneamente perceptual e afetivo, capaz, ao seu modo, de reagir àquilo que experimenta no decurso das peripécias em que se envolve. No interior do campo assim delimitado, vêm situar-se os objetos que tal sujeito pode, quer, deve... conhecer; mas é preciso ter em mente que há, por definição, um "além-campo" correspondente às regiões alheias à capacidade de percepção desse mesmo centro observador.

Para nos referir aos actantes posicionais, falaremos, acolhendo os termos do semioticista francês, em uma fonte do ato perceptivo, em seu alvo correlativo e, enfim, em um "actante de controle", instância não necessariamente actorializada em personagem do relato, e que regula o grau de acessibilidade daquele sujeito perceptual aos objetos perceptíveis. $\mathrm{O}$ actante de controle pode estar representado, digamos, pelas circunstâncias do entorno em que se encontram esse alvo e essa fonte perceptivos, circunstâncias que facilitam (como, por exemplo, um dia límpido, uma janela aberta) ou dificultam (como uma noite enevoada, um biombo) o contato entre eles. Fonte e alvo da cena perceptiva, além disso, são passíveis de se sincretizar numa mesma personagem - em termos mais rigorosos, num mesmo ator do nível discursivo de análise -, como no caso de um sujeito a se mirar numa superfície espelhada. No nosso exemplo, o compositor faz valer os muitos matizes dessa instância da mediação perceptiva, as vitrines, que por trás de seus 
vidros mostram objetos às vezes mais, às vezes menos dóceis à nossa curiosidade.

Se admitirmos esse quadro, a canção "As Vitrines" fala dos estados de ânimo de um sujeito apaixonado que, o tempo todo, dá um jeito, na qualidade de actante posicional, de se manter bem ou mal em conjunção com o objeto de seu desejo, ou seja, a amada, mas sem que esse contato essencialmente visual chegue a concretizar-se na conjunção maior que ele almeja na qualidade de actante transformacional; em outras palavras, por mais que ele a persiga e vigie, a mulher continua a escapar-lhe. Para sua tristeza, é ao sujeito da percepção, mais que ao da junção, que acontecem coisas nesse enredo. Essa dupla condição, que para o sujeito é a mola de um discreto mas contínuo sofrimento, está emblematizada logo no primeiro verso, onde se diz que o sujeito vê a amada "sumir" por aí. O verbo vem, na ocorrência, subsumir as acepções de "sair do campo de visão", "desaparecer", por uma parte, bem como de "perder-se", por outra. Não é só nisso que se reencontra a dupla condição desse vigia enamorado; o componente musical já exibia, na última seqüência, um descompasso entre o modo de desenvolvimento por graus conjuntos da melodia e os efeitos de adiamento da conjunção produzidos pelas dissonâncias harmônicas. É por essa razão que somos levados a associar o sujeito da percepção visual à programação globalmente mais previsível da curva melódica, ao passo que o sujeito juntivo se encontra ligado à inconcludência característica da harmonia que a conduz.

Os episódios relatados são expostos sem que possamos enquadrá-los numa repousante sequiência de começo, meio e fïm; ao contrário, o enunciador nos propõe uma série de lances da permanente perseguição da amada pelo seu espectador (perceptivo) /expectador (juntivo), de tal maneira dispostos que não chegamos a atinar com o porquê do início e do final do texto. Disso decorre a sensação de uma busca infinita, de uma temporalidade que passa a ser conhecida menos em função das mudanças de estado - visto que estas não chegam efetivamente a se realizar - do que em função do tempo de exposição à qual, dia após dia, repetidamente, o desejo compele o sujeito, voyeur inesgotavelmente curioso, a submeter a mulher amada. 
Esta é apresentada sempre a fazer coisas, sempre envolvida numa ação em curso, sem nunca parar para se desprender das múltiplas atividades que a "distraem" e vir enfim saciar a sede de contato do outro. Vai se formando, assim, um efeito de progressividade contínua da ação dessa mulher, que se traduz em movimento, tanto mais vão para o observador quanto este se sabe excluído dos seus itinerários e projetos. Na instância verbal, essa progressividade se mostra nos verbos predominantemente conjugados no tempo presente ou no gerúndio. $\mathrm{Na}$ instância musical, é o jogo, estabilizado somente na última estrofe, das divergências entre a regularidade melódica e as surpreendentes disposições dos acordes dissonantes que estão subjacentes à linha do canto.

Ao longo dos versos de "As Vitrines", o que marca a mulher, objeto do olhar daquele sujeito-primeira pessoa, é uma dupla característica de evanescência, por um lado, e de passagem, por outro. O que ela faz é deixar o campo de visão do sujeito desejante, depois de evoluir diante dele. $\mathrm{O}$ verbo mais freqüentemente associado à mulher é passar, com uma primeira aparição ao final da terceira estrofe, mais duas em idêntica posição inicial dos versos 19 e 20 . A recorrência desse fazer situa a atuação narrativa da amada predominantemente numa dimensão pragmática, que é a das pessoas entretidas nas mil e uma atividades, mais ou menos banais, da vida cotidiana: é uma passante, quase no sentido baudelairiano do termo. Quanto ao amante, o verbo que mais o acompanha é ver, com o que ele fica marcado pelo domínio do sensível, na sua dupla interpretação perceptiva e afetiva; único verbo que aparece em todas as estrofes, pode vir no infinitivo (v. 13 e 20) ou em formas conjugadas (quatro ocorrências, duas delas na terceira estrofe). Convém notar que os verbos que se referem à ação da mulher acham-se freqüentemente subordinados, do ponto de vista sintático, a outros verbos que dizem respeito à percepção visual. É assim no verso 1 , em que o sujeito vê a amada "sumir por aí"; no verso 9, em que ele a vê "suspirar de aflição / E sair da sessão, frouxa de rir"; também no verso 11, em que ela é vista "brincando". Essa subordinação sintática das gesticulações da personagem feminina à captação sensorial e emotiva do sujeito pode até dar lugar a imbricações mais elaboradas, como é 
o caso nos versos 13 e 14: "Nos teus olhos também posso ver / As vitrines te vendo passar", em que o fazer dela é filtrado pelas vitrines, para ser recolhido pelo sujeito que domina sintaticamente o conjunto. Isso posto, a situação fala de um homem fascinado por aquela que ele deseja, e portanto subjugado pelo poder de atração desse seu objeto.

Esse sujeito narrativo, que no decorrer do tempo ("um dia depois de outro dia") vai sendo impressionado pela mulher a quem, como uma sombra, ele obscuramente persegue, é representado pelo mesmo "eu" que, ao final do percurso, vai se encarregar de "catar a poesia" emanada do seu objeto de contemplação para compor a canção. Nesse momento, ele, que na qualidade de "eu-narrativo" só fazia colher furtivas "sobras" das ações cotidianas dela (actante catante), já cumprirá o papel de um "eu-enunciador" (actante contante), dominando, num outro plano de análise, a totalidade do processo, uma vez que será só pela visão desse enunciador que nós, ouvintes, teremos acesso ao mundo reportado. Não é apenas a letra, e sim a canção em seu conjunto, que deixa transparecer essa dupla condição do "eu", personagem da história relatada e ao mesmo tempo simulacro do enunciador; como vimos anteriormente (cf. a primeira parte da análise), também na melodia se percebem, em diferentes momentos, as intervenções desse enunciador, que se manifestam como extravios locais do projeto melódico geral.

\subsection{A cena perceptiva}

O desenrolar dos acontecimentos em "As Vitrines", narrado em primeira pessoa, mostra o amálgama, na mesma personagem, de dois actantes. Estamos chamando ao primeiro de "enunciador" (actante da enunciação) e ao segundo de "eu-narrativo" (actante do enunciado). Este último está representado por uma personagem que evolui no mesmo plano da outra com a qual contracena, a figura feminina, e seu fazer é essencialmente perceptivo: ele sente e avalia a presença e o afastamento da mulher desejada. Quando ao primeiro actante, sua atuação consiste em dizer o que está se passando nas cenas observadas. Acontece, em certos pontos, de ele intervir direta 
e inesperadamente, quebrando a continuidade da linha narrativa que se esboçava. É o que se nota logo na primeira seqüência da canção. A um início de narrativa que parecia tender a constituir uma regularidade do enunciado (v. 1 e 2) sucedem, de repente, quatro versos de irrupção bruta do enunciador, postos em destaque por uma série de marcas singularizantes: na letra, são duas injunções positivas seguidas de duas negativas, com todos os verbos no imperativo; na melodia, é a ruptura com os padrões até então pressentidos, para dar lugar a quatro breves trechos de menor previsibilidade tonal, e marcados pela relativa instabilidade entoativa que caracteriza, mais do que o canto, a fala coloquial.

Longe de ser um observador estático das movimentações da amada, o amante a persegue através das galerias comerciais e também vai atrás dela numa sessão de cinema à qual é difícil afirmar que tivessem ido juntos: "Eu te vi suspirar de aflição / E sair da sessão, frouxa de rir". As vitrines, compartimentos montados para exibir coisas à curiosidade do nosso olhar, são percebidas "por tabela", por meio dos olhos da mulher desejada, sendo o homem, nessa ocorrência como na precedente, um observador de segundo grau. Mais: ao mesmo tempo que os olhos da amada, fonte do seu olhar, estão sob observação do amante, as vitrines ganham um traço / animado/ e tornam-se capazes de ver passar a mulher em foco. Analogamente, no verso 9, o amante vê a amada a "suspirar de aflição", e não há como não perceber que também aí as posições são comutáveis, bastando lembrar a acepção de suspirar como "reagir com suspiros a algo inatingível", que bem define a posição dele a observá-la - muito embora ela, a mulher, não o veja nem tampouco o ouça ("Te avisei que a cidade era um vão").

Hesitação comparável aparece nos versos 11 e 12, com os quais tem início a segunda parte da composição. Nessa passagem, se é razoável compreender o "brincar" como atividade da personagem feminina, já aquele "gostar de ser" que lhe sucede prestase a uma dupla interpretação: (i) como atributo da mulher, que, ao brincar, está "gostando de ser", pura e intransitivamente, avaliando ela mesma aquilo que é e faz, avaliação que o seu pretendente adivinha; (ii) como atributo do homem, que está "gostando de ser a 
sombra" da outra, numa leitura que privilegia a continuidade entre os versos 11 e 12, e que repercute uma mesma dubiedade de demarcações também existente entre os versos 2 e 3 . Lendo o trecho de acordo com a primeira dessas interpretações, estamos reativando no texto de Chico a memória de um conhecido poema de Fernando Pessoa, cujos versos iniciais são:

$$
\text { [5-12-1927] }
$$

Brincava a criança

Com um carro de bois.

Sentiu-se brincando

E disse, eu sou dois!

Há um a brincar

E há outro a saber,

Um vê-me a brincar

E outro vê-me a ver.

$[\ldots]$

Fernando Pessoa - Poesias Coligidas / Inéditas 1919-1935. In: Obra Poética. Rio de Janeiro: Aguilar, 1965, p. 510.

Desdobramento de funções actanciais do mesmo ator, que se reencontra em ambas as personagens aqui enfocadas, sem dúvida, mas com uma diferença fundamental, a transitividade do projeto do homem, chave da sua inquietude passional, em contraposição à intransitividade da mulher, que apenas cuida da própria vida, inconsciente da paixão que desperta.

Há portanto uma série de trocas de posição entre os actantes confrontados no campo perceptivo, que nos dão uma idéia dos estados passionais daquele que relata em primeira pessoa a história, e essa ambigüidade actancial encontra correspondência em outras oscilações presentes na letra. É, conforme acabamos de dizer, o que se passa entre os versos 2 e 3 , onde ocorre uma ambigüidade cuidadosamente calculada para a leitura: se lemos o verso 2 como um todo autônomo, o verso seguinte é uma injunção do amante à amada ("-Dá tua 
mão"), numa irrupção de discurso direto, como num diálogo teatral. Se, ao contrário, interpretamos o verso 3 como vinculado ao anterior pelo dispositivo poético do enjambement, vamos então ler o dístico da seguinte maneira: "Te avisei que a cidade era um vão da tua mão": a presença da amada acaba por englobar o espaço todo da cidade, ultrapassando-o com folga e fazendo prevalecer a sua intensidade afetiva sobre a vasta extensão do entorno urbano. ${ }^{2}$ Logo em seguida, com a súplica "-Olha pra mim”, o sujeito, que não pára de olhar para a mulher, demonstra ansiar pela troca de papéis fonte/ alvo, ou seja, pela instauração de uma reciprocidade que irá buscar permanentemente, sem que isso venha a se realizar. Como quem conhece o modo de agir do interlocutor, nessa interlocução simulada que inventa de si para si, o sujeito dessa busca vai multiplicando as maneiras de tentar manter contato com a mulher; se não deu resultado a dupla injunção positiva dos versos 3 e 4 , em que pedia propriamente uma conjunção ("- Dá tua mão / - Olha pra mim"), ele partirá, nos versos 5 e 6, para um novo pedido que é uma injunção negativa, no afã de preservar ao menos uma não-disjunção ("- Não faz assim / Não vai lá, não”). São duas posições identificáveis pelo critério da junção, e que podem ser visualizadas assim:

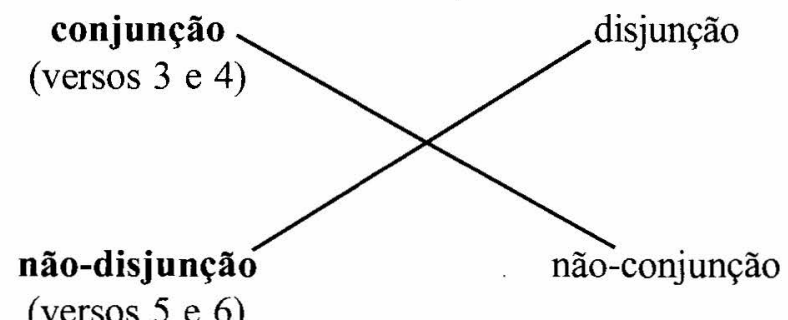

Nesse esquema, as posições da conjunção e da não-disjunção, apesar de aparentadas, distinguem-se como uma versão plena (conjunção) e uma versão imperfeita (não-disjunção) da união entre

2. O encarte do LP original transcrevia a letra dessa composição em uma disposição especial, justaposta a reproduções em espelho, em que o texto cantado retornava em uma versão paralela, entremeada de novas combinações anagramáticas. Nessa versão paralela, o verso 3 é transcrito "Da tua mão". 
o sujeito e seu objeto, ambas figurando sucessivamente nessa pequena encenação, nessa conversação imaginária em que o desejante projeta a mulher desejada.

É preciso apontar as diferentes perturbações da visão que o narrador anota. Na letra cantada: "Eu te vejo sumir por aí", primeiro verso. A visão corre atrás de alguém que se afasta e enfim deixa seu campo perceptivo, sem contudo perder a condição de objeto desejado. "Os letreiros a te colorir / Embaraçam a minha visão", versos 7-8. Esse embaraço da visão do amante está associado à multiplicidade perceptiva: múltiplos letreiros a colorir o corpo da amada (estrofe 2), a sombra da amada a se multiplicar (estrofe 3), múltiplos clarões a iluminá-la (estrofe 4). Variedade de cores (letreiros a colorir) e de luminosidade (sombra, clarões) que cumpre aquela função de "actante de controle", acima definida, inscrevendo no próprio ato perceptivo a dificuldade de conjunção experimentada pelo protagonista a quem foge o objeto almejado. Com tudo o que separa as duas composições, isso não pode deixar de evocar uma antiga canção iniciada por uma cena semelhante:

\section{ARRANHA-CÉU}

(Silvio Caldas-Orestes Barbosa, 1937)
Cansei de esperar por ela, toda a noite, na janela, vendo a cidade a luzir nesses delírios nervosos dos anúncios luminosos, que são a vida a mentir... $[\ldots]$

Nessa que é igualmente uma canção de expectativa ambientada na noite de uma cidade grande, como "As Vitrines", o sujeito do relato contempla anúncios luminosos que alegorizam as ilusões da vida. No texto de Chico Buarque, o turvamento da visão responde por um efeito do mesmo tipo, apesar de não se poder, no seu caso, rotular o estado passional do eu-narrativo como unicamente 
de sofrimento; vimos, há pouco, que o "vigia" da canção de Chico tira também alguma fruição do permanente adiamento do encontro efetivo com a amada, pois que assim ele pode ao menos desfrutar, "da platéia", as situações vividas por ela, além de inventar a seu belprazer diálogos imaginários em que as relações entre eles são de intimidade, conforme está dito na estrofe inicial. De resto, ao aguardador postado à janela, de Silvio Caldas e Orestes Barbosa, vem contrapor-se a mobilidade já assinalada do observador de "As Vitrines", que vai sempre ao encalço do seu fugaz objeto.

Ao concluir, o sujeito resume sua condição: é um "vigia catando a poesia" que a mulher derrama negligente no chão. Olhos cravados nela, a esse vigia só interessa um único objeto de contemplação em meio à variedade de coisas expostas pelas vitrines, e por isso a motivação desse seu "ir catando" incessantemente recomeçado ganha um valor a mais. Não se trata apenas do humilde gesto de quem, do chão e da sombra, recolhe ao longo do tempo a preciosa substância recebida em dádiva involuntária. Catar significa aí, simultaneamente, o gesto de quem cata feijão, selecionando apenas o que quer, do seio da diversidade ambiente, que nesse caso é a da pluralidade embaraçadora da visão. De forma análoga, na música, as organizações mais regulares do projeto entoativo global lutam contra as intervenções dispersivas do enunciador simulado, que tendem aqui e ali ao afastamento da escala fixada.

\section{Para concluir}

Com uma melodia repleta de surpresas que vêm se inscrever no interior de um projeto entoativo globalmente identificável, associada a uma letra não menos trabalhada, "As Vitrines" traz, como obra artística muito singular que é, uma série de desafios para a análise; desta se espera que possa contribuir com os exercícios interpretativos do seu sentido neste ou naquele contexto. ${ }^{3}$ Quem

3. Consulte-se, por exemplo, o interessante comentário de Antonio Carlos Secchin, recentemente incluído na coletânea Chico Buarque do Brasil, organizada por Rinaldo de Fernandes. Rio de Janeiro, Garamond/FBN, 2004. 
contempla vitrines está ao mesmo tempo bem próximo dos objetos expostos, e separado deles pelos vidros transparentes que permitem ver, mas não tocar. Essa dupla condição traduz-se, na canção em apreço, pelos diferentes sinais da conjunção constante entre o sujeito do desejo e a sua amada, no que se refere ao contato visual ("Eu te vejo..."), acompanhados das múltiplas marcas da falta dessa mesma conjunção no que tange, mais afetivamente ainda, ao sentido do tato, representado na primeira das solicitações que o sujeito, em discurso direto, faz à mulher: "Dá tua mão". Carência e prazer mesclados em doses sutis, e que nos são ditos, mediante a mobilização de recursos próprios, pela letra e pela melodia dessa composição. Verificamos que essa equivocidade se propaga, em suma, pelas diferentes instâncias - melódica, perceptiva, actancial, juntiva - em que pudemos contemplá-la.

Buscando sempre a amada com o olhar, segue o sujeito a sucessão dos dias, comparáveis ao ritmo dos clarões que vão iluminando consecutivamente a mulher em seu passeio. História marcada pela visualidade, por certo, mas não por qualquer uma: mais do que as formas, o que impressiona o observador são, nesta ordem, as cores ("Os letreiros a te colorir", v. 7) e depois a luminosidade, com os "clarões" do verso 16 , que vêm ecoar, à distância e em negativo, as múltiplas "sombras" da estrofe anterior. Juntas, constituem as diferentes facetas daquele actante mediador da percepção, a que já aludimos anteriormente.

Em um dos ensaios de seu livro Da Imperfeição (Greimas, 2002, p. 35), Greimas propõe hierarquizar o domínio visual, situando, num percurso do mais superficial em direção ao mais profundo, em primeiro lugar as formas, seguidas das cores, ambas alicerçadas, enfim, num nível fundamental em que não há nada além da luz, pressuposto comum de formas e cores. O sujeito observador de "As Vitrines" está cumprindo, no desenrolar da canção, um roteiro em direção ao mais básico, e nessa perspectiva não é fortuito o fato de ele remeter, no final de sua fala, à poesia entornada no chão. Aí chegado, tem o eu-enunciador uma canção, aquela que ele soube colher a partir da experiência relatada. Contudo, para o outro eu, o narrativo, será apenas mais um dia de vigília, após tantos a perseguir sua paixão - nova perambulação, sempre a mesma. 


\section{Bibliografia}

FONTANILLE, Jacques. Sémiotique $d u$ discours. $2^{\mathrm{a}}$ ed. Limoges: PULIM, 2003.

GREIMAS, A. J. Da Imperfeição. Trad. Ana Claudia de Oliveira. São Paulo: Hacker, 2002.

SECCHIN, A. C. « 'As Vitrines': a poesia no chão ». In : Rinaldo de Fernandes (org.), Chico Buarque do Brasil. Rio de Janeiro: Garamond/FBN, 2004. 